\title{
COMPARATIVE STUDY OF PULMONARY FUNCTION TESTS AMONG SMOKERS AND NON-SMOKERS IN A TERTIARY CARE HOSPITAL IN KOSHI REGION (NORTHERN BIHAR), INDIA
}

\author{
Abdul Rahman Hasan'1, Chandan Kumar Poddar², Bijay Krishna Prasad³, Maheshwar Narayan Singh \\ ${ }_{1}^{1}$ Assistant Professor, Department of Physiology, Lord Buddha Koshi Medical College, Saharsa, Bihar. \\ ${ }^{2}$ Ph.D Research Scholar, Department of Microbiology, Indira Gandhi Institute of Medical Sciences, Patna, Bihar. \\ 3 Professor, Department of Physiology, Anugrah Narayan Magadh Medical College, Gaya, Bihar. \\ 4 Professor, Department of Microbiology, Anugrah Narayan Magadh Medical College, Gaya, Bihar.
}

\section{BACKGROUND}

ABSTRACT

Smoking in India has been known since at least 2000 BC when cannabis was smoked and is first mentioned in the Atharvaveda, which dates back a few hundred years BC. Chronic Obstructive Pulmonary Disease (COPD) has been recognised as one of the most important causes of morbidity and mortality in chronic tobacco smokers all over the world. Cigarette smoking produces inflammatory changes in small airways, especially in respiratory bronchioles. This leads to dilatation and destruction of small airways, characterised as emphysema. The pulmonary damage induced by smoking acts slowly and may show no symptoms until pulmonary functions are lost. In present study, the pulmonary function test of smokers were compared with non-smokers, the people of Northern Bihar (Koshi region), Bihar.

\section{MATERIALS AND METHODS}

The study design is a descriptive comparative study of Lord Buddha Hospital (Central Hospital) and Associated Hospital, Lord Buddha Koshi Medical College, a tertiary care centre in Koshi Region (Northern Bihar) from January 2015 to November 2016. In the study 120 healthy male subjects, 60 smokers and 60 non-smokers were assessed for their pulmonary function test by using a computerised spirometer.

\section{RESULTS}

In the present study, bidi smoking was most common (58.33\%) followed by both cigarette and bidi smoking (25.0\%) and only cigarette smoking (16.67\%) in smokers. The distribution of grade of smoking is shown in Table 3. Light smokers were commonest $(75.00 \%)$, followed by moderate $(21.67 \%)$ and heavy smokers $(03.33 \%)$. Most of the smokers were in the age group of $40-49$ years $(50.0 \%)$. Majority of light smokers (53.33\%) were in the age group of $40-49$ years, moderate smokers (46.16\%) in $50-60$ years and heavy smokers $(50.0 \%)$ in 50 - 60 years.

\section{CONCLUSION}

Tobacco smoking in any form, bidi or cigarette or both has significantly deleterious effects on the pulmonary functions. In this rural study area, bidi smoking was most common. Almost all the pulmonary function parameters were significantly reduced in smokers and obstructive pulmonary impairment was commonest.

\section{KEYWORDS}

Smoking, Smokers, Non-Smokers, Spirometry, Pulmonary Functions, Rural Area.

HOW TO CITE THIS ARTICLE: Hasan AR, Poddar CK, Prasad BK, et al. Comparative study of pulmonary function tests among smokers and non-smokers in a tertiary care hospital in Koshi region (Northern Bihar), India. J. Evolution Med. Dent. Sci. 2018;7(11):1341-1346, DOI: 10.14260/jemds/2018/305

\section{BACKGROUND}

Smoking in India has been known since at least 2000 $\mathrm{BC}$ when cannabis was smoked and is first mentioned in the Atharvaveda, which dates back a few hundred years BC. Tobacco smoking is menace and contagious problem. Every effort is being made at government level to stop smoking. Even it has been declared as a crime and punishable act. Ordinance about penalty to cigarette smokers has been passed, but in spite of all cigarette smokers are still

'Financial or Other Competing Interest': None.

Submission 26-01-2018, Peer Review 27-02-2018,

Acceptance 05-03-2018, Published 12-03-2018.

Corresponding Author:

Dr. Chandan Kumar Poddar,

Ph.D. Students, IGIMS, Patna,

S/o. Sri Late Jagdish Kumar Poddar,

(SE/RLY/KIR) M. G. Road, Durgapur,

Katihar-854105, Bihar, India.

E-mail: chandan_microbiology@yahoo.co.in

DOI: $10.14260 /$ jemds/2018/305

\section{(c) (i) $(9$}

flourishing. Tobacco smoking is an intentionally invited health hazard.

The World Health Organisation reported that tobacco smoking killed 100 million people worldwide in the 20th century and warned that it could kill one billion people around the world in the 21st century.[1] In India, smoking is a prevalent in both urban and rural areas irrespective of mode of smoking i.e. cigarettes, bidis, pipes, cigar, hookah etc. In India, tobacco is consumed mainly in the form of bidis (54\%) followed by smokeless tobacco (27\%) and cigarettes (9\%).[2]

Tobacco has remained as one of the most important predisposing factors responsible for so many respiratory and cardiovascular diseases. Chronic Obstructive Pulmonary Disease (COPD) has been recognised as one of the most important causes of morbidity and mortality in chronic tobacco smokers all over the world.[3]

Tobacco kills more than five million people worldwide. Use of tobacco in smoking and non-smoking form is quite common in India; about $15 \%$ to over $50 \%$ men use tobacco in this country. Thus, tobacco smoke related respiratory 
diseases like COPD, lung cancer etc. are increasing rapidly. Furthermore, tobacco consumption has a deleterious effect on the course of bronchial asthma, pulmonary tuberculosis, lung function and other lung diseases. ${ }^{4]}$ Moreover, there is accelerated decline in lung function if airway obstruction already exists.[5]

Cigarette smoking produces inflammatory changes in small airways, especially in respiratory bronchioles. This leads to dilatation and destruction of small airways, characterised as emphysema.[6] The pulmonary damage induced by smoking acts slowly and may show no symptoms until pulmonary functions are lost.[7]

In a population based Delhi, the prevalence of bronchial asthma and allergic rhinitis was found to be higher than reported earlier from India. Smoking was one of the major risk factors for higher prevalence of bronchial asthma and allergic rhinitis.[8]

Respiratory system evaluation and screening can easily be done by Pulmonary Function Tests. It is an important and useful adjunct for correlation and evaluation of the presenting complaint of patients like cough and dyspnoea, the imaging studies and pre- and post-treatment respiratory function status as well as to identify patients with no or insignificant signs and symptoms of respiratory impairment.

Keeping in mind, the huge physiological and clinical importance I decided to carry out this study. In present study the pulmonary function test of smokers were compare with non-smokers. So, it is expected that this knowledge will help in forming the norms of ventilator functions of Indian subject by giving due weightage to the interfering effect of smoking.

In view of increasing behaviour of smoking among the people of Northern Bihar, where a large population is migrant workers with poor hygiene and low socioeconomic status, this study was undertaken for a better understanding of the correlation between smoking and its effects on pulmonary functions.

\section{MATERIALS AND METHODS}

The study design is a descriptive comparative study, Lord Buddha Hospital (Central Hospital) and Associated Hospital, Lord Buddha Koshi Medical College, a tertiary care centre in Koshi Region (Northern Bihar), from January 2015 to November 2016.

This study was conducted after approval from the Institutional Ethical Committee before the start of study. The study population included 120 male subjects comprising of 60 smokers and 60 non-smoker controls aged between 30-60 years. The study group was amongst general public including staff members, students and healthy attendant of the patients. The approval of Institutional Ethics Committee was taken before the start of study. Participants who met the inclusion criteria were recruited after giving information regarding the study in their vernacular language and written informed consent was obtained.

\section{Classification based upon Smokers and Non-Smokers by WHO (1998)-[9]}

1. Smoker: Someone who, at the time of the study, smokes any tobacco product either daily or occasionally.

2. Non-Smoker: Someone who, at the time of the study, did not smoke at all.
3. Ex-Smoker: Someone who was formerly a daily or occasional smoker, but currently does not smoke at all.

\section{Inclusion Criteria}

1. Subjects in the age range between 30 - 60 years.

2. Non-Smoker: According to definition non-smoker is a person who does not smoke tobacco.

3. Smoker: They are persons who are engaged in the inhalation and exhalation of fumes of burning tobacco from cigarette, bidis etc.

4. Every smoker must have been smoking at least six cigarettes a day.

\section{Exclusion Criteria}

1. Females will be not included in the study.

2. Known case of bronchial asthma.

3. COPD subjects.

4. Chronic infections such as tuberculosis or other infections of lungs.

5. Subjects with respiratory symptoms such as cough.

6. Pneumothorax.

\section{Smoking Index}

The average number of cigarettes/ bidis smoked per day and duration (in years) of tobacco smoking. Further, smokers were classified as per exposure level on the basis of smoking index criteria.[10,11]

\section{Smoking Habit Index}

(Frequency x duration)

Non-smokers 0.

Light smokers 1-10.

Moderate smokers 11-20.

Heavy smokers more than 20.

\section{Before Performing Pulmonary Function Test, following} Points were Ascertained that the-

1. Subject has not consumed alcohol within four hours.

2. Has not smoked within one hour.

3. Has worn comfortable clothing, not restricting chest and abdominal movements.

4. Has not performed vigorous exercise within half an hour.

\section{Procedure of Spirometry}

For this study computerised spirometer, RMS Helios 701 was used. For performing the spirometry, each participant was allowed to rest for about 10 minutes before the procedure. The details of procedure was explained and demonstrated to each participant-

1. Smoking within 1 hour of procedure.

2. Performing vigorous exercise within 30 minutes of procedure.

3. Wearing clothing that substantially restricts full chest and abdominal expansion.

4. Eating a large meal within 2 hours of procedure.

5. To obtain an accurate recording: Sit up straight; Wear nose clip and get a good seal around the mouth.

The subject was asked to sit comfortably in a chair. The complete procedure was explained. All doubts if any are cleared. Subject was instructed to breathe in fully by deep inspiration with nostrils closed. Seal the lips around the 
sterile mouthpiece of spirometer and forcefully expire the air out as fast and as far as possible. Best of three readings was recorded and interpreted.

\section{Statistical Analysis}

The data collected during the study was formulated into a master chart in Microsoft Office Excel and statistical analysis was done with the help of computer using statistical software package SPSS V.17 for windows. Using this software frequencies, range, mean, standard deviation and ' $p$ ' were calculated through student's ' $\mathrm{t}$ ' test and Chi-square test. SPSS software version 17 was used to calculate quantitative variables to check. Percentages were calculated directly for $p=0.05$ was used as the accepted significance level.

\section{RESULTS}

The physical parameters of smokers and non-smokers are shown in [Table 1]. The age range of subjects was $30-60$ years with mean age of 48.25 years in smokers and 48.15 years in non-smokers. Similarly, there was significant difference in the means of other physical parameters like height, weight, body mass index and body surface area in smokers and non-smokers.

In the present study bidi smoking was most common $(58.33 \%)$ followed by both cigarette and bidi smoking (25.0\%) and only cigarette smoking (16.67\%) in smokers [Table 2] [Graph 1].

The distribution of light smokers were commonest $(75.0 \%)$ followed by moderate $(21.67 \%)$ and heavy smokers (03.33\%) [Table 3] [Graph Table 1].

Most of the smokers were in the age group of $40-49$ years $(50.0 \%)$. Majority of light smokers (53.33\%) were in the age group of 40 - 49 years, moderate smokers $(46.16 \%)$ in 50 - 60 years and heavy smokers $(50.0 \%)$ in $50-60$ years [Table 4] [Graph Table 2].

The mean values of all the pulmonary function tests are significantly reduced in smokers compared to non-smokers. The impaired PFTs in smokers were found to be statistically highly significant by applying unpaired ' $\mathrm{t}$ ' test of significance [Table 5] [Graph Table 3].

In our study, obstructive changes were most common in smokers $(36.67 \%)$ followed by restrictive $(3.33 \%)$ changes and mixed (5.0\%) changes. Most of the non-smokers (95.0\%) had normal PFT results [Table 6] [Graph 2].

The relation of type of smoking with pulmonary function tests is shown in [Table 7] [Graph Table 4]. In the present study, bidi smoking was the most common (58.33\%) and it accounted for most of the obstructive lung changes (68.18\%) in smokers after spirometry.

\begin{tabular}{|c|c|c|}
\hline Variables & $\begin{array}{c}\text { Non-Smokers } \\
\text { Mean } \pm \text { 2 S.D.* }\end{array}$ & $\begin{array}{c}\text { Smokers } \\
\text { Mean } \pm \text { 2 S.D. }{ }^{*}\end{array}$ \\
\hline Age (years) & $48.15 \pm 10.54$ & $48.25 \pm 10.09$ \\
\hline Height (m) & $1.66 \pm 0.12$ & $1.67 \pm 0.11$ \\
\hline Weight (kg) & $64.3 \pm 11.5$ & $65.5 \pm 8.8$ \\
\hline $\begin{array}{c}\text { Body surface area } \\
\text { (m2) }\end{array}$ & $1.75 \pm 0.14$ & $1.72 \pm 0.06$ \\
\hline $\begin{array}{c}\text { Body Mass Index } \\
\text { (BMI) }\end{array}$ & $23.81 \pm 3.37$ & $23.53 \pm 3.20$ \\
\hline $\begin{array}{r}\text { Table 1. Physical Characteristics of Smokers and Non- } \\
\text { Smokers People in Northern Bihar }\end{array}$ \\
\hline
\end{tabular}

\footnotetext{
* S.D. $=$ Standard Deviation.
}

\begin{tabular}{|c|c|c|}
\hline Type of Smoking & No. & Percentage (\%) \\
\hline Only Bidi & 35 & 58.33 \\
\hline Both Cigarette/ Bidi & 15 & 25.00 \\
\hline Only Cigarette & 10 & 16.67 \\
\hline Total & $\mathbf{6 0}$ & $\mathbf{1 0 0 . 0}$ \\
\hline \multicolumn{2}{|c|}{ Table 2. Type of Tobacco Smoking in Smokers } \\
\hline
\end{tabular}



Graph Table 1. Type of Tobacco Smoking in Smokers

\begin{tabular}{|c|c|c|}
\hline Grade of Smoker & $\begin{array}{l}\text { Number of } \\
\text { Smokers }\end{array}$ & Percentage (\%) \\
\hline Light smoker & 45 & 75.00 \\
\hline Moderate smoker & 13 & 21.67 \\
\hline Heavy smoker & 02 & 03.33 \\
\hline Total & 60 & 100.0 \\
\hline
\end{tabular}

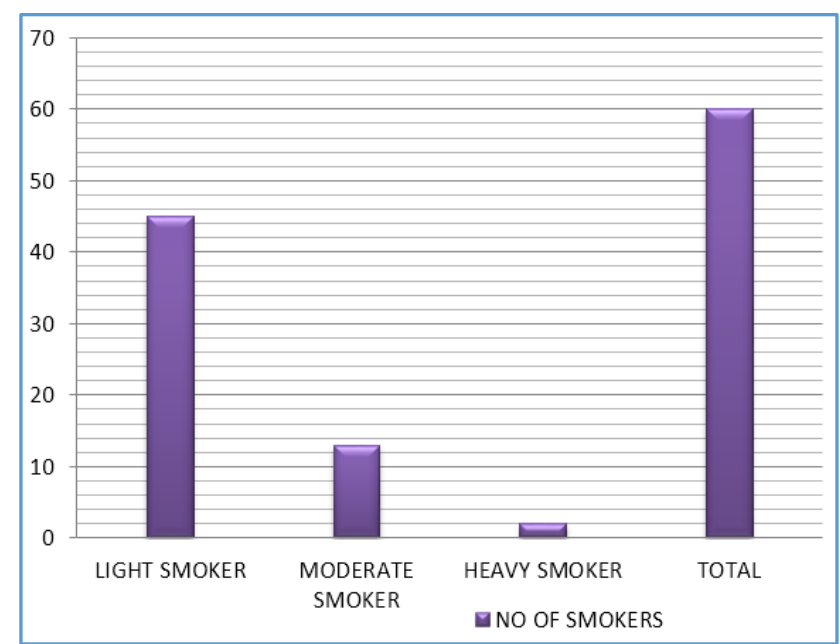

Graph Table 1. Distribution of Grade of Smoking in Smokers

\begin{tabular}{|c|c|c|c|c|}
\hline $\begin{array}{c}\text { Age } \\
\text { Group } \\
\text { (Years) }\end{array}$ & $\begin{array}{c}\text { Light } \\
\text { Smoker } \\
\text { No. (\%) }\end{array}$ & $\begin{array}{c}\text { Moderate } \\
\text { Smoker No. } \\
\text { (\%) }\end{array}$ & $\begin{array}{c}\text { Heavy } \\
\text { Smoker } \\
\text { No. (\%) }\end{array}$ & $\begin{array}{c}\text { Total } \\
\text { No. (\%) }\end{array}$ \\
\hline $30-39$ & $14(31.11)$ & $2(15.38)$ & $0(00)$ & $16(26.67)$ \\
\hline $40-49$ & $24(53.33)$ & $5(38.46)$ & $1(50.0)$ & $30(50.00)$ \\
\hline $50-60$ & $07(15.56)$ & $6(46.16)$ & $1(50.0)$ & $14(23.33)$ \\
\hline Total & $\mathbf{4 5 ( 7 5 . 0 0 )}$ & $\mathbf{1 3 ( 2 1 . 6 7 )}$ & $\mathbf{2} \mathbf{( 0 3 . 3 3 )}$ & $\begin{array}{c}\mathbf{6 0} \\
\mathbf{( 1 0 0 . 0 )}\end{array}$ \\
\hline
\end{tabular}

Table 4. Age Wise Distribution of Grade of Smoking in Koshi Region, Bihar 


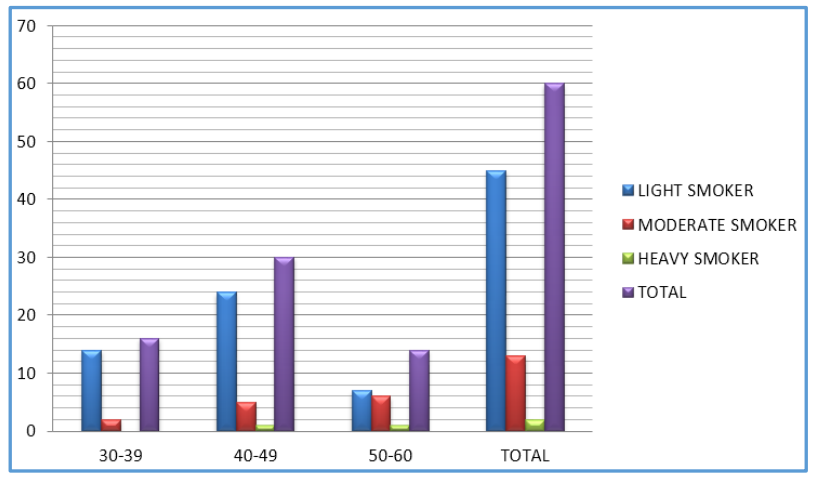

Graph Table 2. Age Wise Distribution of Grade of Smoking

\begin{tabular}{|c|c|c|c|}
\hline $\begin{array}{c}\text { Pulmonary } \\
\text { Function Tests } \\
\text { (PFTs) }\end{array}$ & $\begin{array}{c}\text { Non-Smokers } \\
\text { Mean } \pm 2 \text { S.D* }\end{array}$ & $\begin{array}{c}\text { Smokers } \\
\text { Mean } \pm 2 \text { S.D }\end{array}$ & $\begin{array}{c}\text { Significance* } \\
\text { P value }\end{array}$ \\
\hline FVC & $3.14 \pm 0.98$ & $2.97 \pm 1.06$ & 0.03241 \\
\hline FEV1 & $2.82 \pm 0.86$ & $2.47 \pm 1.02$ & 0.000697 \\
\hline FEV1/FVC & $89.48 \pm 10.54$ & $83.95 \pm 23.97$ & 0.003811 \\
\hline PEFR & $6.81 \pm 3.44$ & $5.31 \pm 3.45$ & 0.000037 \\
\hline FEF 25\%-75\% & $3.59 \pm 1.74$ & $2.98 \pm 2.02$ & 0.00193 \\
\hline MVV & $102.6 \pm 33.66$ & $86.2 \pm 44.21$ & 0.00002 \\
\hline $\begin{array}{c}\text { Table 5. Pulmonary Function Tests among Non-Smokers } \\
\text { and Smokers in Koshi Region, Bihar. P value Less Than } \\
\text { O.05 is Significant }\end{array}$ \\
\hline
\end{tabular}

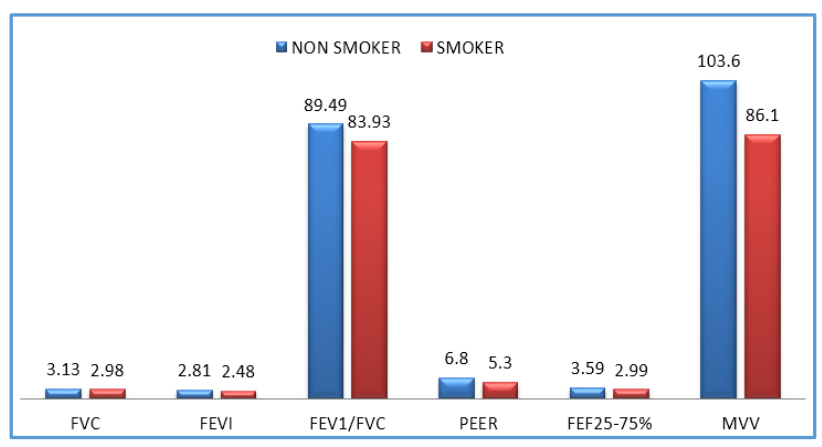

Graph Table 3. Pulmonary Function Tests among Smokers and Non-Smokers

\begin{tabular}{|c|c|c|c|}
\hline PFT Results & $\begin{array}{c}\text { Smokers } \\
\text { No. (\%) }\end{array}$ & $\begin{array}{c}\text { Non-Smokers } \\
\text { No. }(\%)\end{array}$ & $\begin{array}{c}\text { Total } \\
\text { No. }(\%)\end{array}$ \\
\hline Obstructive & $22(36.67)$ & $03(05.00)$ & $25(20.83)$ \\
\hline Restrictive & $02(03.33)$ & $00(00.00)$ & $02(01.67)$ \\
\hline Mixed & $03(05.00)$ & $00(00.00)$ & $03(02.50)$ \\
\hline Normal & $33(55.00)$ & $57(95.00)$ & $90(75.00)$ \\
\hline Total & 60 & 60 & $120(100.0)$ \\
\hline
\end{tabular}



Graph 2. Interpretation of PFT Results in Smokers

\begin{tabular}{|c|c|c|c|c|c|}
\hline \multirow{2}{*}{$\begin{array}{c}\text { Type of } \\
\text { Smoking }\end{array}$} & \multicolumn{4}{|c|}{ Pulmonary Function Test Interpretation } & \multirow{2}{*}{ Total } \\
\hline & Obstructive & Restrictive & Mixed & Normal & \\
\hline Only Bidi & $\begin{array}{c}15 \\
(68.18) \\
\end{array}$ & $\begin{array}{c}0.0 \\
(0.0) \\
\end{array}$ & $\begin{array}{c}03 \\
(100.0) \\
\end{array}$ & $\begin{array}{c}17 \\
(51.52) \\
\end{array}$ & $\begin{array}{c}35 \\
(58.33) \\
\end{array}$ \\
\hline $\begin{array}{c}\text { Both } \\
\text { Cigarette/ } \\
\text { Bidi } \\
\end{array}$ & $\begin{array}{c}05 \\
(22.72)\end{array}$ & $\begin{array}{c}02 \\
(100.0)\end{array}$ & $\begin{array}{c}0.0 \\
(0.0)\end{array}$ & $\begin{array}{c}08 \\
(24.24)\end{array}$ & $\begin{array}{c}15 \\
(25.00)\end{array}$ \\
\hline $\begin{array}{c}\text { Only } \\
\text { Cigarette }\end{array}$ & $\begin{array}{c}02 \\
(09.00) \\
\end{array}$ & $0.0(0.0)$ & $\begin{array}{c}0.0 \\
(0.0) \\
\end{array}$ & $\begin{array}{c}08 \\
(24.24) \\
\end{array}$ & $\begin{array}{c}10 \\
(16.67) \\
\end{array}$ \\
\hline Total & $\begin{array}{c}22 \\
(100.0) \\
\end{array}$ & $\begin{array}{c}02 \\
(100.0) \\
\end{array}$ & $\begin{array}{c}03 \\
(100.0) \\
\end{array}$ & $\begin{array}{c}33 \\
(100.0) \\
\end{array}$ & $\begin{array}{c}60 \\
(100.0) \\
\end{array}$ \\
\hline Table 7 & elation b & veen of $P$ & Ilmonar & Function & \\
\hline
\end{tabular}

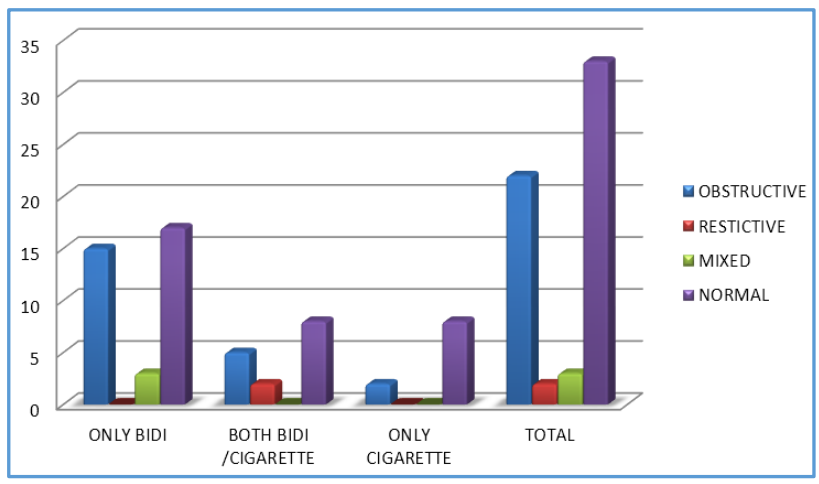

Graph Table 4. Relation of Type of Smoking with Pulmonary Function Tests

\section{DISCUSSION}

Smoking is well-known to cause respiratory disorders and pulmonary functions decline and when it co-exists with air pollution the effects could be more harmful. Tobacco smoking is widely prevalent all over the world and it continues to rise in developing countries. By 2030, the developing world is expected to have 7 million deaths annually from tobacco use.[12]

World Health Organisation 1993 tobacco alert report, 900 billion bidi sticks are smoked per year in India alone. The national family health survey 2005 - 2006 reported $29.0 \%$ men and $8.9 \%$ women smokers, in state of Bihar, India. Cigarette smoking predominates in urban areas, where bidi smoking is the commonest type of smoking in the lower income groups of illiterate and less educated people.[13]

This study included data on 120 subjects in the age group of 30-60 years with 60 non-smokers and 60 smokers. The study observed decreased pulmonary functions in smoker population compared to the non-smoker population. It is showed that there were statistically significant changes in pulmonary function ("p" value $<0.05$ ) between smoker and non-smoker population.

There was significant difference in the mean physical parameters like age, height, weight, body mass index and body surface area by calculating mean and standard deviation in smokers and non-smokers, thereby showing proper matching of smokers and non-smokers (Table 2). Most of the smokers smoked only bidi (58.33\%) followed by both cigarette and bidi mixed (25.0\%) and only cigarettes $(16.67 \%)$. None of the individuals smoked tobacco in any form other than bidis or cigarettes.

Most cigarette smokers usually smoked non-filter cigarettes since. They are cheap and easily available in rural areas. Also, most smokers belonged to rural background and were of low socio-economic status. 
In the smoking index it was observed that most smokers were light smokers (42.0\%) followed by moderate smokers (32.0\%) and heavy smokers (26.0\%).

In our study majority of the light smokers were in the age group of 40 - 49 years (53.33\%), moderate smokers in 50 - 60 years $(46.16 \%)$ and heavy smokers in $50-60$ years $(50.0 \%)$. Similarly, Burrows et al,[14] reported that there is quantitative significant relationship between impaired ventilatory function and duration and frequency of smoking.

In our study all pulmonary function parameters like FVC, FEV1, FEV1/FVC, PEFR, FEF 25\% - 75\% and MVV showed statistically highly significant association between smokers and non-smokers by applying unpaired t-test of significance ( $p<0.001$ ). Similar, observations showing lung function impairment in smokers were reported by Burrows et al,[14] Pandya et al.[15]

In our study out of total 120 study subjects 90 (75.0\%) had normal lung functions, whereas $30(25.0 \%)$ had impaired lung functions out of which $27(90.0 \%)$ were smokers and only $3(10.0 \%)$ were non-smokers. The association between smoking and impaired PFT was statistically highly significant. The smokers had 17.3 times more risk of having impaired pulmonary functions as compared to non-smokers. A fall in FVC indicates restrictive lung changes.

In the present study, obstructive lung dysfunction was commonest among those with impaired pulmonary functions in both smokers (22 out of 27, i.e. in $81.48 \%$ ) and nonsmokers group (3 out of 3 subjects, i.e. in 100.0\%).

The obstructive lung changes were predominantly in only bidi smokers 15 (68.18\%) followed by in both cigarette and bidi smokers $05(22.72 \%)$ and only cigarette smokers 02 (09.00\%). Padmavathy, $[16]$ in a study concluded that pulmonary functions are more affected in bidi smokers than in cigarette smokers.

The diagnostic difficulties encountered were parallel to those experienced by different authors working on similar projects- Smoking is the major identified risk factor and approximately $15 \%$ of smokers developed Chronic obstructive pulmonary disease (COPD). [17] Current cigarette smoking had the higher rate of infection with C. pneumoniae. Smoking is a well-known important risk factor for COPD patients through alteration in mechanisms of the host defense system.[18,19]

Comparing the burden of tuberculosis and COPD- The aetiological agent in tuberculosis is the bacillus Mycobacterium tuberculosis which represents one of many in the family of mycobacteria. The mode of spread among humans is via aerosol droplet transmission, hence the lungs are often the focus of tuberculous disease although TB may present with disease in any organ system. In the 1998 survey of TB cases in England and Wales, $62 \%$ were noted to exhibit pulmonary involvement.[20] In that survey, 38\% had sole extrapulmonary involvement and this figure appeared to be increasing when compared to previous surveys undertaken in the same region. $[20,21,22,23]$

Lung involvement due to non-typhoid strains of Salmonella was first recognised in patients with underlying conditions such as malignancy, diabetes mellitus, corticosteroid therapy or alcohol abuse.[24] Salmonella has been rarely cited as a significant respiratory pathogen in this population. $[25,26,27]$
Studies on the prevalence of COPD in patients with HCV are also scant. In patients with chronic HCV infection, prevalence of COPD (17.6\%) and bronchial asthma (14.7\%) is significantly higher compared to that in patients with hepatitis B infection matched in age, gender and smoking status (COPD 5\%, bronchial asthma 1.7\%).[28,29,30] Bacterial Vaginosis are also including passive cigarette smoking status.[31]

\section{CONCLUSION}

Tobacco smoking in the form cigarette-bidi has significant deleterious effects on the pulmonary functions. In this study in rural area, bidi smoking was the most common. Almost all the pulmonary function parameters were significantly reduced in smokers and obstructive pulmonary impairment was commonest finding. There was significant decreased pulmonary function in the smoker population in comparison to the non-smoker population. Hence, the risk of respiratory mortality or morbidity is high with chronic tobacco smoking in Koshi region, Bihar.

\section{REFERENCES}

[1] WHO report: Tobacco could kill one billion by 2100 . Science Daily 2008 Aug, 24:71.

[2] Anonymous. IUALTD: The world tobacco situation. IUALTD News Bull Tobacco Health 1998;11:19-21.

[3] Abdullah ASM, Husten CG. Promotion of smoking cessation in developing countries: a framework for urgent public health interventions. Thorax 2004;59(7):623-30.

[4] Behera D. Respiratory Medicine in India in the 21st century. Indian Journal of Chest Diseases and Allied Sciences 2008;50:179-81.

[5] Chhabra SK, Rajpal S, Gupta R. Pattern of smoking in Delhi and comparison of chronic respiratory morbidity among beedi and cigarette smokers. Indian J Chest Diseases and Allied Sciences 2001;43(1):19-26.

[6] Gold DR, Wang X, Wypij D, et al. Effects of Cigarette smoking on lung function in adolescent boys and girls. The New England Journal of Medicine 1996;335(13):931-7.

[7] Downs SH, Brandli O, Zellweger JP, et al. Accelerated decline in lung function in smoking women with airway obstruction: SAPALDIA 2 cohort study. Respiratory Research 2005;6:45.

[8] Bhargava EK, Khaliq F. Effect of paternal smoking on the pulmonary functions of adolescent males. Indian J Physiol Pharmacol 2008;52(4):413-9.

[9] World Health Organization. Guidelines for controlling and monitoring the tobacco epidemic. WHO, Geneva, 1998;76-101.

[10] Gupta SK. Respiratory disorders among workers in a railway workshop. Ind J Tub 1995;42:161.

[11] Zodpey SP, Ughade SN. Tobacco smoking and risk of age-related cataract in men. Regional Health Forum, WHO South-East Asia Region, 2006;3:336-46.

[12] Fraig M, Shreesha U, Savici D, et al. Respiratory bronchiolitis. A clinicopathologic study in current smokers, ex-smokers, and never-smokers. Am J Surg Pathol 2002;26(5):647-53. 
[13] Gaur SN, Gupta K, Rajpal S, et al. Prevalence of bronchial asthma and allergic rhinitis among urban and rural population of Delhi. Indian Journal of Allergy, Asthma and Immunology 2006;20(2):90-7.

[14] Burrows B, Khudson RJ, Clline MG, et al. Quantitative relationship between cigarette smoking and ventilatory function. Amer Review Resp Dis 1977;115(2):195-205.

[15] Pandya KD, Dadhani AC, Chandwani S. Effect of physical trainings, age, sex, posture and smoking on peak flow rates. Indian J Physioland Pharmacol 1984;28(3): p. 38.

[16] Padmavathy KM. Comparative study of pulmonary function variables in relation to type of smoking. Indian J Physiol Pharmacol 2008;52(2):193-6.

[17] Sethi JM, Rochester CL. Smoking and chronic obstructive pulmonary disease. Clin Chest Med 2000;21(1):67-86.

[18] Straus WL, Plouffe JF, File TM, et al. Risk Factors for domestic acquisition of Legionnaires disease. Ohio Legionnaires Disease Group. Arch Intern Med 1996;156(15):1685-92.

[19] Kumar R, Ejaz SK, Poddar CK, et al. Screening IgM and IgG antibodies to chlamydophila pneumoniae by enzyme immunoassay (EIA) in paediatric LRTIs in a tertiary hospital experience in Koshi area (Northern Bihar), India. J Evolution Med Dent Sci 2016;5(86):6357-59.

[20] Rose A, Watson J, Graham C, et al. Tuberculosis at the end of the 20th century in England and Wales: results of a national survey in 1998. Thorax 2001;56(3):1739.

[21] Kumar D, Watson JM, Charlett A, et al. Tuberculosis in England and Wales in 1993: results of a national survey. Public Health Laboratory Service/British Thoracic Society/Department of Health Collaborative Group. Thorax 1997;52(12):1060-7.

[22] Ahmad I, Mishra A, Poddar CK, et al. Comparison of Ziehl-Neelsen stains with fine needle aspiration technique in diagnosis of tuberculous lymphadenitis in tertiary care hospital, South Bihar (India). J Evolution Med Dent Sci 2017;6(63):4598-602.
[23] Singh MN, Lal A, Poddar CK, et al. Efficacy of fineneedle aspiration technique, Ziehl-Neelsen stains and culture (BACTEC) in diagnosis of tuberculous lymphadenitis in tertiary care hospital, Gaya, India. J Evid Based Med Healthc 2017;4(70):4164-9.

[24] Wolfe MS, Louria DB, Armstrong D, et al. Salmonellosis in patients with neoplastic disease: a review of 100 episodes at Memorial Cancer Center over a 13 year period. Arch Intern Med 1971;128(4):546-54.

[25] Jacobs JL, Gold JW, Murray HW, et al. Salmonella infections in patients with the acquired immunodeficiency syndrome. Ann Intern Med 1985;102(2):186-8.

[26] Ejaz SK, Poddar CK, Singh MN, et al. Antimicrobial susceptibility of salmonella enterica serovars in a tertiary care hospital in Koshi region (Northern Bihar), India. J Evolution Med Dent Sci 2017;6(22):1808-11.

[27] Taylor KI, Coker RJ, Clarke J, et al. Pulmonary complications of HIV disease: 10 year retrospective evaluation of yields from bronchoalveolar lavage, 1983-93. Thorax 1995;50(12):1240-5.

[28] Singh MN, Lal A, Poddar CK, et al. Comparative evaluation of ELISA and rapid screening techniques for the diagnosis of $\mathrm{HCV}$ in haemodialysis patients in tertiary care hospital, South Bihar, India. J Evolution Med Dent Sci 2017;6(93):6683-7.

[29] Ahmad I, Mishra A, Poddar CK, et al. Sensitivity comparison of ELISA and rapid screening techniques for the detection of HBsAg among chronic liver disease (CLD) patients in a tertiary care hospital, south Bihar, India. J Evolution Med Dent Sci 2017;6(71):5045-9.

[30] Erol S, Saglam L, Ozbek A, et al. Hepatitis C virus infection and chronic obstructive pulmonary disease. Hepatitis Monthly 2009;9(1):39-44.

[31] Krishna S, Prasad BK, Poddar CK, et al. A study of prevalence of bacterial vaginosis in sexually active females - a cross-sectional study in tertiary care hospital, Gaya. J Evid Based Med Healthc 2018;5(5):419-24. 